\title{
Land Scarcity, Family Relocation and Settler - Host Community Relations: The Experience of Relocated Families in Machinga and Mangochi, Southern Malawi
}

\author{
Paul Kishindo \\ Department of Rural Sociology \\ University of Malawi \\ P.O. Box 280 \\ ZOMBA \\ Malawi
}

\section{Abstract}

Malawi has a skewed land distribution pattern characterized by the co-existence of large estates and smallholdings. This is largely attributable to colonial and postcolonial agricultural policies which favoured large scale export - oriented agriculture as the engine of economic development over subsistence oriented smallholder agriculture. In many of the agriculturally rich areas of the country, smallholders were pushed onto marginal lands with resultant poor agricultural output. In a country that is still industrially underdeveloped agriculture remains the principal means of livelihood and land shorlage easily translates into poverty. The Malawi government with financial assistance from the World Bank is implementing a five year pilot project to relocate land poor families onto estates bought from willing sellers. This paper examines the dynamics of the relationship between the new immigrants and their host communities. 


\section{Introduction}

Malawi is a landlocked country occupying some 118, $484 \mathrm{sq}$ $\mathrm{km}$ of which $94,276 \mathrm{sq} \mathrm{km}$ is land area. An estimated $56 \%$ of the land is considered arable. The country's population is currently estimated at 12 million. The annual population growth rate is estimated at $3 \%$. More than $80 \%$ of the population derive their livelihood from agriculture. Access to land is regarded by many Malawians as a basic right whether or not they are in paid employment. Those in paid employment expect to return to the village when they retire, while for those not in paid employment land represents a basic means of survival.

A combination of government policies and rapid population growth has created land scarcity especially in the southern region to the extent that newly formed households can only access land for subsistence production though splitting up existing holdings. The resulting plots have tended to be too small for the subsistence and cash requirements of an average family. Rural food insecurity and low household income are associated with land shortage. Beginning July 2004 the Malawi government with financial assistance from the World Bank is implementing a project, called the Community Based Rural Land Development Project (CBRLDP), aimed at resettling land poor families onto estates from the four pilot districts of Mangochi, Machinga, Mulanje and Thyolo onto land bought from willing private owners. The project is a new approach to land redistribution based on market assisted transactions and community driven processes. The goal of the project is to contribute to poverty reduction in the pilot districts with the possibility of scaling up across the country. The specific objectives of the project are:

- to improve land delivery systems of accessing, titling and registration.

- to provide security of tenure 
- to increase agricultural productivity

- to increase incomes

About 15000 poor families are expected to benefit from the project by its conclusion. By the end of August 20061749 families had relocated to new sites in Machinga and Mangochi. This paper analyses the process of resettlement and the dynamics of settler - host community relations. Whenever two or more groups with different aspirations, social and cultural backgrounds meet there is bound to be some tension, and possible conflict. How successfully these potential conflicts are mitigated and actual ones are resolved is critical to harmonious intergroup relations.

\section{The Genesis of the Land Problem}

Malawi began its existence as a geopolitical entity in 1891 as the protectorate of British Central Africa following intense lobbying by Scottish missionaries who had arrived in the Shire Highlands on an evangelization mission in 1875.' The declaration of British protectorate status was meant to thwart the territorial ambitions of the Portuguese who had earlier settled to the south at Sena, Tete and Quelimane in Mozambique but were from 1882 beginning to lay claim to the area which the missionaries regarded as their sphere of influence (Warhurst 1971:28). Sir Harry Johnston was appointed the first Commissioner and Consul General with a mandate to make it economically self - sufficient as soon as possible so that it did not become a permanent drain on the imperial treasury.

The Commissioner was convinced that economic development of the protectorate could be achieved through the development of large-scale export - oriented agriculture. The European planters who had followed in the wake of the

'The Shire Highlands consisted of what are now Blantyre, Chiradzulu, Thyolo, Mulanje and Zomba districts in Southern Malawi 
missionaries had through their tea and coffee plantations already provided a basis for this development (Kandawire 1979:459; Krishnamurthy 1972: 384). The Commissioner apparently did not envision the African as anything other than a subsistence producer or labourer on the European - owned plantations. Two important decisions were made by the Commissioner, the effect of which was to transfer productive land to the export crop producing European settler:

- He gave legitimacy to European occupation of land obtained form African chiefs under various agreements by issuing "Certificates of Claim"

- He acquired on behalf of the British crown "all waste and unoccupied land" from which leases would be granted to new settlers.

The "Certificate of Claim" was issued in respect of a concession where the Commissioner was satisfied that adequate consultation with a chief had occurred and reasonable consideration had been paid. What constituted "reasonable consideration" was never defined, considering that some of this land was acquired for a string of beads, a few meters of calico cloth, a bottle of brandy or whisky, blanket, a gun or gun power. The question whether African chiefs had the right to sell land, or whether the transaction was a sale at all, was never addressed. The formalization of land through "Certificates of Claim" immediately deprived indigenous communities of about 1400000 hectares of prime agricultural land (Krishnamurthy 1972: 385). Mulanje and Thyolo were the most affected by this policy. The legacy of this policy is the present situation whereby Malawian families own less than 0.4 ha while the tea and coffee estates occupy between $700-$ 8000 ha (Chanthunya 1999: 14). The landless and near landless farmers are compelled by circumstances to sell their

${ }^{2}$ Although not clearly defined, tenure status was believed to be akin to freehold. 
labour to the estates in order to survive. The tea and coffee companies take advantage of the desperate situation of landless families to pay them wages which are often below the statutory minimum.

Successive governors ${ }^{3}$ of the protectorate continued to promote the development of an of agricultural export economy with minor concessions to African where they were allowed to grow some low value cash crops such as cotton.

Colonial rule left as its legacy a system of individualized ownership of land existing parallel to the pre - existing system of customary tenure where access to land was a matter of right. This dualism was reflected in a bimodal agricultural economy which the Africa - led government inherited on attaining self government in 1963.

\section{The Post - Independence Situation}

Soon after attaining independence in 1964 efforts was made to raise the productivity of the Malawian dominated smallholder sector by channeling most government resources to that sector. It was believed that such efforts would help rural households achieve marketable surpluses and improve their cash incomes. During that period efforts were made to deal with the problem of African landlessness in Mulanje and Thyolo districts through the purchase or compulsory acquisition of unutilized and underutilized estate land. Some of this acquired land formed the basis of the Smallholder Tea Authority created in 1967 to give an opportunity to Malawians to grow what was hitherto regarded as a European crop. The land redistribution exercise was, however, not sustained because doubts were being raised within government regarding the ability of smallholder agriculture to generate economic growth and provide sufficient revenue for investment purposes. The estate sector with its large holdings and potential for borrowing

\footnotetext{
${ }^{3}$ The Office of Commissioner and Consul General were renamed "Governor".
} 
investment capital was seen as a firmer basis for economic growth and source of revenue for the state than the smallholder sector (Mkandawire 1992: 179). Since tea was the major foreign exchange earner in the economy at the time, it did not appear to be economically prudent to attempt the acquisition and breaking up of established estates for redistribution. Government may also have feared accusation of racism if such a course of action was followed. In the final analysis economic and political considerations prevailed over the demands of equity and social justice.

The perpetuation of the unequal distribution of land has created a situation whereby food insecurity is a permanent feature of rural households in Mulanje and Thyolo as they fail to produce enough food on their tiny holdings. It was estimated in 1995 that $40 \%$ of children aged under five years in Mulanje, and $43 \%$ in Thyolo, were stunted due to long term chronic malnutrition. The population of the two districts also exhibited the highest incidence of wasting in the country at $12 \%$ and $14 \%$ respectively, while $36 \%$ of the children aged under five years in the two districts were underweight (Chilowa et al cited in Steele et al 1997:46).

While the land problem in the tea growing areas may be considered a colonial legacy the post - independence government is solely responsible for extending it to other areas hitherto unaffected such as the central and northern region. The unfettered powers to dispose of customary land enjoyed by the minister responsible for land matters under the Land Act $1965^{4}$ were used extensively in the 1970 s and 1980 s to grant leases out of customary land for the purpose of tobacco production. Under the Special Crops Act 1963 (repealed in 1996) certain specified crops, which included flue cured and burley tobacco, could only be grown under certain conditions. A licence was needed to grow the two tobacco varieties which

\footnotetext{
${ }^{4}$ The minister may, for example, compulsorily acquire customary land for a public purpose without prior consultation with chiefs; and he/she may lease customary land to individuals and corporations for periods of up to 99 years.
} 
were in great demand on the world market during that period; but such licence could only be given to people with access to leasehold and freehold land (UN in Malawi and Malawi Government 1993:83). The policy of restricting burley and flue cured tobacco to leasehold and freehold land holders was based on the assumption that such tenure systems provided adequate security for investment as opposed to customary land which provided only the right to use. This policy requirement led to a rush to acquire leases in those areas that were deemed suitable for tobacco production. No limit was placed on the amount of land that could be leased. Kasungu, Mchinji and Lilongwe districts in the central region; Rumphi and Mzimba in the northern region; and Mangochi and Machinga in the southern region were affected by this policy whose major beneficiaries were the political elite, civil servants and businessmen. The World Bank reports that between 1977 and 1983400000 ha of customary land was transferred to leasehold tenure (World Bank 1987:12). By 1997 some 1200 000 ha of productive land had been leased by tobacco growers (Gossage 1997:7). As much as $29 \%$ of suitable land on tobacco estates was found to be underutilized in 1997, and many estates, especially in the northern region lay abandoned (Presidential Commission on Land Policy Reform 1999: 82). It is apparent that some individuals encouraged by low land taxes had acquired more land than they had the capacity to develop.

Under the current Land Act lapsed leases revert to the state as public land and may be leased again at the discretion of the minister. In this way productive land was lost from the stock of customary land available for use by smallholders.

Until 1994 when emphasis in economic policy shifted from agriculture to smallscale business development the rhetoric was that tobacco production would be the engine of national economic growth, although the exact dynamics of this

${ }^{5}$ Lease periods for agricultural estates range from $7-33$ years. 
development and how the rural communities whose ancestral land was converted to agriculture leases would benefit was never fully explained.

In continuing policies that encouraged large scale production of high value export crops while simultaneously promoting smallholder food production for national food self sufficiency the post - independence government perpetuated the bimodal agrarian system of the colonial period with its attendant competition for land, labour and other resources between the two subsectors. The resource - poor and politically unconnected subsistence farmer was the inevitable loser in this competition.

\section{Redressing the Land Problem}

By 1985 it became clear to the government that the conversion of customary land into leasehold tobacco estates had engendered antagonism between local communities and estate owners, who were in most cases strangers in the community, and that corrective action needed to be taken before the situation went out of control. In that year a ministerial directive was issued that no more estates would be opened in Kasungu where the problem was greatest. The Control of Land (Agricultural Leases) Order 1989 partially formalized that order except that it did not apply to customary landholders who wanted to convert their holdings to leasehold tenure. The Order was amended in 1996 to prohibit the conversion of customary land to leasehold except in special cases which were never fully defined. In that same year the Special Crops Act 1963 which had fueled the expansion of the estate sector was repealed. The repeal of this Act meant that fluecured and burley tobacco could be grown on customary land thus removing the need to acquire leases or convert customary holdings into leases. But by the time these measures were 
taken much customary land had already been converted into leaseholds. Those who were currently holding leases were allowed to keep them and nothing was said about their status when they expired. It can therefore be assumed that expired leases would in terms of the Land Act (currently in use) would still revert to the state as public land.

A more important initiative was taken by the government in March 1996 when the President appointed a Commission of Inquiry into Land Policy Reform with a mandate to undertake a broad review of land problems throughout the country, and recommend the main principles of a new land policy which would foster a more economically efficient, environmentally sustainable and socially equitable land tenure system (Government Notice No 20 of 1996). The commission submitted its report to the President in October 1999. A new land policy based on the recommendations of the commission and further consultations with stakeholders was adopted by cabinet in January 2002.

The land policy, which will be backed by appropriate legislation ${ }^{6}$ seeks to correct many of the problems that arose as a result of socially insensitive agricultural policies and the absence of a comprehensive land policy. In the policy the government inter alia, declares its intention to acquire land by negotiation and purchase for the resettlement of landless and near - landless households. An estimated 3500 households (between $15000-20000$ persons) is believed to need land as a matter of urgency (Ministry of Lands, Physical Planning and Surveys 2003: 28). These are people that are land deficient and vulnerable to chronic food insecurity.

\footnotetext{
${ }^{6}$ Submission of the relevant bill to parliament has stalled principally because of opposition by traditional leaders to sections which appear to dilute their authority over customary land.
} 


\section{The Community Rural Land Development Project}

\section{(CBRLDP)}

To qualify for inclusion in the land acquisition project the applicants must be Malawi citizens, who are landless or land poor and facing recurrent food insecurity. They must also be willing to form a voluntary group for the purposes of identifying a farm, purchasing it, settling on it, and undertaking the necessary developments. In the final analysis the potential beneficiaries are a self - selected group willing to leave their accustomed social and natural environment for the prospect of improving their economic well being in a different environment. It is also possible that the project provided an opportunity to escape social tensions and conflicts that may or may not be land - related.

Community Oversight Committees, made up of elected members of "sending" communities verify the bonafides of applicants. Eligible households organise into Beneficiary Groups. Beneficiary Groups consist of not less than 20 and not move than 35 households. In turn each Beneficiary Group elects a Project Management Committee. This committee, with the help of project officials identifies a farm, negotiates purchase and arranges its occupation. The Project Management Committee manages the finances of the Beneficiary Group and resolves intragroup post - relocation conflicts, and forms the official link between Project Management and relocated households. Community Oversight Communities in the "receiving" communities, also elected, ensure that the new arrivals are properly received and adapt quickly to the new environment.

Each relocated household is entitled to a Uniform Ceiling Grant of Malawi Kwacha equivalent of US\$1050 for the purchase of land, resettlement costs and farm development (Ministry of Lands, Housing and Surveys 2005, Annex 2). These grants are used in accordance with strict guidelines set by government and can only be accessed through commercial 
banks. This situation necessitates that the Project Management Committees travel long distances to the towns where the banks are located.

\section{Relocation and Resettlement}

Resettlement entails leaving a familiar environment, friends and part of one's history. The decision to relocate to new areas has never been an easy one to make. The potential benefits of such a decision have to be significant. It is known, for example, that in the flood - prone district of Chikwawa in the southern region, many households have resisted relocation to upland areas because it would entail abandoning the graves of their ancestors which is considered taboo.

The relocation of Beneficiary Groups in the Community Based Rural Land Development project began in November 2005. By March 2006 four Beneficiary Groups comprising of 126 families had relocated to newly acquired lands and by the end of August 200669 Beneficiary Groups comprising 1749 households had relocated. All relocations were within or to Machinga and Mangochi. The fact that Mulanje and Thyolo had not received any relocated households is an indication of the unavailability of land for purchase in those districts, and by extension, the reluctance of the large landowners to sell their land to landless poor people.

Out of the relocated Beneficiary Groups, 19 came from Mulanje and Thyolo and therefore had crossed district boundaries. The long distances between the vacated villages and their newly acquired homes would make it difficult to maintain regular contact with friends and kin in the vacated villages. This loss of regular contact was regretted by many relocated households. The ideal situation as perceived by the relocated households would be to relocate to an area that was not too far from one's home to facilitate visits between members of the extended family. Yet closeness to the settler's 
home village would work against the project's goal of permanent settlement as beneficiaries might be tempted to treat the new sites only as "work places"

\section{Intercommunity Relations}

The project envisages as the ultimate outcome of the relocation process the permanent settlement and integration of relocated households into their new communities. A situation of contact between groups is one of potential conflict as they may hold different social and cultural values. Competing economic interests are also a potential source of conflict. Yet contact could also be mutually rewarding.

The Yao and Lomwe form the largest proportion of relocated households. These two ethnic groups have much in common, for example, they follow a system of matrilineal descent, practice uxorilocal forms of marriage and emphasize the role of initiation ceremonies in the socialization of the young. However, the Yao are predominantly Moslem while the Lomwe tend to be Christian one group that stands out is that from one area of Thyolo district which relocated to Machinga and is made up predominantly of Ngonis who follow a patrilineal system of descent and succession and tend to be christian.

Cultural conflict in situations of contact is likely to occur where

- One group perceives its culture to be superior and seeks to impose it on another group.

- One group openly despises and ridicules another group's culture as being inferior.

- Members of one group fail to understand the significance of certain cultural practices and symbols.

Although no incidents of cultural conflict were recorded during the field visits there exist areas of potential conflict 
between the Ngoni group and their Yao hosts. Pig, rearing and eating is so much part of Ngoni culture; yet pigs, partly because of islamic influence, are regarded as dirty animals and therefore not acceptable as livestock or food by the Yao. If in future resettled households attempted to rear pigs they might encounter hostility from their islamized hosts.

Group interviews with members of the host community revealed that the arrival of the relocated households in November 2005 created an opportunity for local people to earn cash through the sale of labour for ground preparation, planting and other tasks. The extra labour enabled the new arrivals to plant in time for the rains; while the local people were able to meet their basic needs such as soap, sugar, salt and paraffin.

This is a mutually beneficial situation. It might be expected that as the resettled households prosper economically from increased productivity, the chances for local employment would also increase

On the other hand, resentment was harboured by members of communities hosting two of the Beneficiary Groups. The cause of the resentment was that the community receiving the relocated households were themselves land short and had expected to benefit from a redistribution of the underutilized estate land in their midst. The land that was acquired by the "strangers", it is claimed, had originally belonged to the community before it was "illegally" bought by the previous owners who had failed to fully develop it and create employment for the local unemployed people. The arrival of the relocated households effectively ended their hopes of re acquiring the land. Encroachment on the land had begun even before the arrival of the relocated households and continued even after their arrival. The problem of encroachment is likely to continue this growing season unless the traditional leaders, who apparently give tacit approval to this behaviour, and project management can find a solution that is acceptable to both sides. 
One group in Machinga had to contend with neighbours demanding a share of farm inputs that they had bought for their holdings. The perception here is that the settlers are "favoured children of government" and were receiving free inputs and money while the local people were excluded. It is significant to note that the Beneficiary Group that experienced this behaviour was the Ngoni group that had settled among the Yao in Machinga. It is likely that the situation would have been less confrontational if the in - coming group was not so different from the host community.

The picture that emerges from the resettled areas in Machinga and Mangochi is mixed: in some areas the new arrivals have been welcomed as potential employers of labour where income - earning opportunities are very limited; while in some areas they are viewed as competitors for land. It is possible that those who welcome the new arrivals are interested in earning cash to alleviate their poverty as workers than they themselves becoming market producers; while those who resent the new arrivals might be aspiring to become market producers themselves.

\section{Conclusion}

The ultimate outcome of the project is the resettlement of land poor households in new areas where they are able to acquire larger landholdings than they had in the vacated areas. It is the expectation of the project planners that the resettled households would treat the new sites as home and not as mere places of economic opportunity which they can abandon after reaping the anticipated benefits. But permanent settlement in a new place is itself the result of an interplay of many factors, of which the attitude of the host community is an important. In general communities tend to be hostile to in-coming groups who constitute a potential threat to their access to important resources or their accustomed way of life. 
The resettled households in Mangochi and Machinga have blocked the prospects of local land - poor households accessing land which they believe rightfully belongs to them. The encroachments that have been experienced so far are an attempt to lay claim to the lost land. Large scale encroachment could have the effect of driving out the relocated households.

A case can be made for giving priority to local people to acquire estates that are available for sale in their locality. In the absence of a programme of compulsory land acquisition and redistribution, this would ensure that members of the community who lost their customary land can re-acquire some of it. Participation of local people in the land acquisition exercise would remove the perception of exclusion which tends to engender hostility against in-coming groups.

In the final analysis, it can be argued that a land redistribution programme based on market transactions is unsustainable in a poor country like Malawi. When World Bank funds run out in 2009 there is no guarantee that more funds will be available to continue the programme. Yet the number of land - poor households is increasing every year. 


\section{References}

Chanthunya, C. (1999) Financial and Economic Returns to Land: A StudyUudertakenforthe Presidential Commission on Land Policy Reform.

Chilowa W. et al (1995) UNICEF Multiple Indicator Cluster Study cited in Steele R. Bosworth J., Gossage S and Mataya C. (1997) The Tea Plantations of Malawi: the Report of the Tea Estates Survey 1996 - 1997).

Gossage C. (1997) Land Use on the Tobacco Estates of

\section{Malawi}

Government No 20, March 18, 1996

Kandawire, J. (1979) Thangata: Forced Labour or Reciprocal Assistance? Zomba: University of Malawi Research and Publications Committee.

Krishnamurthy, B. (1972) "Economic Policy: Land and Labour in Nyasaland. 1890 - 1914" in Pachai, B (ed) The Early History of Malawi London: Longman.

Ministry of Lands, Physical Planning and Surveys (MLLPS) 2003 The National Land Policy.

Mkandawire, R. (1992) "The Land Question and Agrarian Change in Malawi. In Mhone, G. (ed) Malawi at the Crossroads: the Postcolonial Economy. Harare: SAPES Trusts.

Nankumba, J. and Machika M (1988) Dynamics of Land Tenure and Agrarian Systems in Africa: the Case of Malawi. Report to the Food and Agriculture Organization (FAO).

United Nations in Malawi and Malawi Government (1993) Situation Analysis of Poverty in Malawi Lilongwe: UNICEF.

Warhurst, P. (1971) "Portugal's Bid for Southern Malawi, 1882 1891 in Pachai B., Smith G. and Tangri R. (ed) Malawi Past and Present Blantyre: CLAIM.

World Bank (1987) Malawi: Land Policy Study 


\section{(c) 1 (i) (9)}

This work is licensed under a

Creative Commons

Attribution - NonCommercial - NoDerivs 3.0 License.

To view a copy of the license please see:

http://creativecommons.ora/licenses/bv-nc-nd/3.0/

This is a download from the BLDS Digital Library on OpenDocs

http://opendocs.ids. ac.uk/opendocs/ 